\title{
An Empirical Study on the Relationship between Foreign Investment and International Trade in Bangladesh
}

\author{
Mohammad Zillur Rahman \\ Assistant Professor, School of Business Studies, Southeast University \\ Room \# 209, House \# 64, Road\# 18, Block-B, BananiDhaka-1213. Bangladesh. \\ Tel: +88-029-882-340 ext. $308 \quad$ Email: zillur_rahman@seu.ac.bd
}

Received: May 13, $2011 \quad$ Accepted: June 29, $2011 \quad$ doi:10.5430/ijfr.v2n2p33

\begin{abstract}
Bangladesh is home to large unskilled and semi-skilled population and lacks adequate domestic employment opportunity due to scarcity of foreign direct investment (FDI) which may foster its economic growth. And this country has also been experiencing significant increase in international trade in recent years compared with the scenario of last decade. In this backdrop, the author aims at empirically searching whether these FDI and international trade bolster or hinder growth of each other or not. Taking Bangladesh data of imports, exports and FDI covering the period between 1972-2007, the test for cointegration could not reject the hypothesis of no cointegration $(r<0)$ among the variables in question and the paper only found foreign direct investment to have granger caused import but similar causality in any other direction was not found.
\end{abstract}

Keywords: FDI, Trade, Cointegration, Granger causality, Error-correction model

\section{Introduction}

Foreign investments and international trade are focus of researchers for the enormous influence of these phenomena on the overall economy of any nation in the world. Research findings do not conclusively point to the direction of causality between trade and investment and due to significant role of them in the growth dynamics of various economies, empirical research works have been endeavored in this connection. The author of this paper has also attempted to look into the direction of causality between foreign direct investment and international trade in case of Bangladesh.

On the trade front, Bangladesh has been continuously experiencing greater contribution of trade to its gross domestic product measured by 'Trade openness'. Table 1 is a proof of the previous statement. Trade openness rose fast from 29.16 percent in FY1998-99 to 42.22 percent in FY2006-07 according to Bangladesh government data.

On the contrary, Bangladesh like other regional neighbors has not been very successful in attracting foreign investment. Even though South Asia is attractive destination for foreign investors, having high and steady economic growth, less than $10 \%$ inflation, huge domestic markets (more than 1.5 billion people), a gradually increasing number of skilled people, a growing pool of enterprising group of people in addition to improving financial systems and vibrant capital markets, these economies have not lived to its potential in terms of attracting foreign investments (Sahoo, 2006). Like Brazil, China, Singapore and other East and Southeast Asian countries, these countries have not obtained huge flow of FDI in general and particularly among developing Asian economies. South Asia has only received 3 percent of FDI inflow (Sahoo, 2006). Bangladesh and other South Asian countries have been adopting favorable policies about attracting FDIs since the 1990s.Except India; other economies of this region have not successfully attracted FDI even after adopting liberalized policies including incentives for investors (Sahoo, 2006).

Over the past 20 years, FDI flows across countries have increased enormously, which is a sign of the globalization of the world economy (Busse and Groizard 2005). Many developing countries, since the early 1980s, recognizing the necessity of FDI, have made room for more inflow of capital from abroad. The post-cold-war political reality in the world has also made acquiring foreign investment more essential as the flow of aid fell sharply from the USA to its allies of cold-war period. According to the World Bank estimates, since the 1980s FDI inflow in all developing countries has grown by almost $672 \%$, while the regional breakdown for the same during that period has been: Europe and Central Asia - 5,200\%, East Asia and Pacific - 942\%, South Asia - 740\%, Latin America and Caribbean - 455\%, and Sub-Saharan Africa - 59\% (World Bank 2000). In dollar terms, total global FDI flows increased from some US \$55 billion in 1985 to US \$1,511 billion before falling back to US $\$ 573$ billion in 2003 (World Bank 2005). Ozturk (2007) estimates that as a share of gross domestic product (GDP), FDI has become more significant over time. In high-income countries, it increases from 
around 0.5 to 1.0 per cent in the 1980 s to more than 5 per cent in 2000 and then declines to 1.4 per cent in 2003 (Busse and Groizard,2005). In low and middle-income countries, the percentage of FDI in GDP remains at more than 2 per cent after the year 2000, implying higher significance of FDI flows in developing countries during this period. Yet, despite the big jump in FDI inflows, the share of the region in global FDI flows remains negligibly small. While the average annual share of developing countries in global FDI inflows during 2004-06 has been over 32 per cent, South Asia accounted for only 1.7 per cent of the global FDI inflows. In addition, for none of the countries (except Pakistan) the average ratio of FDI inflows to gross fixed capital formation in 2004-06 was higher than for developing countries combined (Aggarwal,2008).

Apparently 'factor-proportion hypothesis' (Helpman, 1984; Markusen, 1984; Helpman and Krugman, 1985; Ethier and Horn, 1990) predicts complementarity between trade and FDI when firms integrate vertically across border taking advantage of factor price differences (Chaisrisawatsuk S. and Chaisrisawatsuk W. 2007).

The relationship of complementarity or substitutability between FDI and trade depends on the nature of the former as evident in the literature (Helpman, 1984; Markusen, 1984). Theories on FDI classify it into two broad categories, namely- horizontal and vertical FDIs to find the relationship between FDI and trade and according to these theories, horizontal and vertical FDIs have negative and positive relationships respectively with trade. Domestic investment and FDI outflows complement each other in the realm of industrial vertical integration and these two are substitutes when industry integrates horizontally (Chaisrisawatsuk S. and Chaisrisawatsuk W, 2007). Within a particular industry, as evident in the aforesaid study, international trade and investment are complementary. However, FDI and trade in goods can be linked bidirectionally, argue Aizenman and Noy (2005) and the Granger causality from FDI flows to trade openness is proved to be stronger than that from trade to FDI flows in their study using Geweke's (1982) decomposition method.

Cross-sectional studies on firm and industry-level data from the US and Swedish multinationals (Lipsey and Weiss, 1981 and 1984;Blomström et al., 1988) point to a positive relationship between foreign affiliate sales and exports, resulting from foreign investment, for both countries, though it has been positive in case of few US industries.

On the other hand, more recent studies utilizing time-series data reveal varied outcome. For example, data on time-series relationship between manufacturing exports and FDI covering 11 OECD countries since the 1970s, prove the linkages between investment and exports across countries to be heterogeneous (Pain and Wakelin, 1998). Ramstetter (1991) and Svensson (1996) also confirm such relationship.

The empirical research by Samsu et al. (2008) using the vector error correction model can not find causality in the short run between FDI inflows and exports, but validates the long-run positive effect from investment inflows to exports. Similar studies also indicate that if the investor and recipient economies of FDI vary widely regarding resource endowments, then the host country export can be expanded (Liu et al., 2001). This, in turn, proves that FDI improves export performance also.

Similarly, Dollar (1992) and Jun and Singh (1995) hypothesize that the economies exploiting export potential heavily also attract more foreign direct investment. Having studied foreign direct investment and balance of payments position of Malaysia, Phang (1998) argues that countries featuring greater trade potential and export do attract more foreign investment than others and suggests trade policy supporting promotion of those sectors capable of drawing significant inflow of FDI to expedite export growth.

To make the effective use of FDI, host economies should identify its comparative advantage and very importantly FDI should supplement but not substitute for capital resources (Samsu et al.,2008).

The economic literature also bears evidence of substitution effects of trade on investment and vice versa against the complementary relationship between these two variables. The multinational enterprises expand production horizontally across border due to increased transaction costs, originating from greater trade barriers and transportation costs (Krugman, 1983; Horstmann and Markusen, 1992; Brainard, 1993 \& 1997), it implies that international trade and investment are substitutes (Chaisrisawatsuk S. and Chaisrisawatsuk W, 2007). A significant contribution to the debate of complementarity-substitutability between trade and investment has been made by Blonigen (2001) based on his findings from product level data on Japanese production and exports to the US for automobile parts and automobiles. Blonigen (2001) proves that exports of final goods substitute FDI and trade between intermediate goods and affiliate sales is complementary.

Significant growth in the economy through capital formation and transfer of technology, as argued by neoclassical growth theorists, is the most apparent contributions of FDI to growth of various nations (Blomström et al., 1996; Borensztein et al., 1995), and De Mello (1997, 1999) suggests that FDI making MNEs (multinational enterprises) also 
improve the level of knowledge of their host-country employees through labor training and skill acquisition.

Having substantially worked on economic growth, Chowdhury and Mavrotas (2005), also find evidence of significant effect of FDI on economic growth in the forms of capital formation, achievement of technology spillover, human capital (managerial know-how and skill) enhancement, creation of job opportunities and so on. However, certain factors are crucial for obtaining positive effect of FDI on economic growth, including the human capital base in the host country, financial market regulations, banking system, condition of infrastructure, economic/political stability etc.

Unlike other capital flows, FDI is less volatile and does not behave in a pro-cyclical manner; hence, it has been the "favorite capital inflows" (Ozturk, 2007) for developing countries since 1990s- characterized by fluctuations of capital flows.

Again FDI's role in economic growth, as evident in the research literature, depends on the level of development of countries receiving foreign investment, as Ozturk (2007) finds this to be positive for the developing countries, and in the case of FDI recipient developed countries, no growth occurs.

Findings of Wheeler and Mody (1992) suggest that rapid economic growth is an important determinant of FDI destinations making South Asian countries including Bangladesh a suitable one for the prospective investors.

FDIs may accompany pure externalities (like facilitating adoption of technology), not pecuniary externalities (result of the effects of FDI on market structure) though quantifying these effects is very difficult, as suggested by Saggi( 2000).

Multinational firms, entering a foreign market through FDI, bring newer technologies to that market and compete with the host-country firms using these advanced technologies and technology is thus transferred (contagion effect ; Findlay, 1978).

An interesting aspect of technology transfer is identified by Keller (1996). In this study, the author argues that while a country fails to change the human capital even after accessing foreign technologies, then foreign investment can not bring much good, it is further supported by Borensztein et. al. (1998).

Less developed countries (LDCs) need to avail new technologies of developed countries (DCs) for fostering their growth and this technological diffusion will enable LDCs graduate from their present status to the next level of development (Ozturk, 2007). And FDI can be the means of bringing these new technologies to the LDCs.

For Bangladesh, along with other South Asian economies, therefore, it is imperative to attract FDI for faster economic growth specially because these countries are heavily populated (i.e. untapped human resources) and cannot unlock its vast potential due to scarcity of other necessary resources including financial capital, advanced technological buildup and other infrastructural support to name a few.

In increasing the productivity level of huge unemployed and poverty-stricken people of Bangladesh, the plausible way of rapid growth is through the fruitful accumulation and productive use of foreign investment. This investment is capable of enhancing knowledge, skill and subsequently productivity of these people of this country, as is argued by numerous growth models in the economic literature (Harrod,1939; Domar,1946; Solow,1956;Lucas,1988; Rebelo,1991; Romer,1986 \&1990; Helpman and Grossman,1991; Bajpai and Sachs, 2000).

In terms of utilization of FDI, according to FDI Performance Index of World Investment Report, UNCTAD (2005) Pakistan and Bangladesh have performed better than large economies, such as India in FDI performance. And in case of policy reform, Bangladesh and Sri Lanka has liberalized more than India recently (Sahoo, 2006), but the comparison of FDI performance over years between 1990 and 2003 do not show that Bangladesh did well.

This empirical research is a replication of existing literature taking available recent data from Bangladesh. Its findings can substantiate the argument in favor of long-term trade and investment relationship as evident in the findings.

\section{Data and Methodology}

The data series being used in this paper are obtained from World Development Indicators (WDI) of World Bank covering period between 1972 and 2007. Data are current values of foreign investment inflow, export and import from the said source and has undergone $\log$ transformation initially to reduce data variability.

The multivariate Granger methodology (proposed by Granger and popularized by Sims in 1969 and 1972 respectively) is applied to identify direction of causality among the variables of interest, i.e. foreign direct investment, export and import. Consider the following vector autoregression (VAR) representation, 


$$
\left[\begin{array}{l}
F D I_{t} \\
E X P_{t} \\
I M P_{t}
\end{array}\right]=\left[\begin{array}{l}
c_{1} \\
c_{2} \\
c_{3}
\end{array}\right]+\left[\begin{array}{lll}
\Phi_{11}(L) & \Phi_{12}(L) & \Phi_{13}(L) \\
\Phi_{21}(L) & \Phi_{22}(L) & \Phi_{23}(L) \\
\Phi_{31}(L) & \Phi_{32}(L) & \Phi_{33}(L)
\end{array}\right]\left[\begin{array}{l}
F D I_{t} \\
E X P_{t} \\
I M P_{t}
\end{array}\right]+\left[\begin{array}{l}
\varepsilon_{1 t} \\
\varepsilon_{2 t} \\
\varepsilon_{3 t}
\end{array}\right]
$$

where, FDI, EXP and IMP denote three potentially endogenous variables: foreign direct investment, exports and imports, respectively, $L$ is the lag operator, and $\varepsilon_{1 t} \varepsilon_{2 t}$ and $\varepsilon_{3 t}$ are white noise errors. The null of no joint significance of parameters of lagged variables of interest can be tested using $F$-tests.

Empirical works based on time series data assume that the underlying time series is stationary. However, many studies have shown that majority of time series variables are nonstationary or integrated of order 1 (Engle and Granger, 1987). The time series properties of the data at hand are therefore studied in the outset.

The above specification (equation-1) of the causality test assumes that the time series at hand are mean reverting process. However, it is highly likely that variables of this study are nonstationary. Formal tests are carried out to find the time series properties of the variables. If the variables are I (1), Engle and Granger (1987) assert that causality must exist in, at least, one direction. The Granger causality test is then augmented with an error correction term (ECT) as shown below: $\Delta F D I_{t}=\beta_{0}+\sum_{i=}^{m} \beta_{1 i} \Delta F D I_{t-i}+\sum_{2}^{m} \beta_{2 i} \Delta E X P_{t-i}+\sum_{i}^{m} \beta_{3 i} \Delta I M P_{t-i}+\beta_{4} Z_{t-1}+\varepsilon_{1 t}$ $\Delta E X P_{t}=\varphi_{0}+\varphi_{1 i} \Delta E X P_{t-i}+1 \varphi_{2 i} \Delta F D I_{t-i}+\varphi_{3 i} \Delta I M P_{t-i}+\varphi_{4} Z_{t-1}+\varepsilon_{2 t}$ $\Delta I M P_{t}=\delta_{0}+\sum \delta_{1 i} \Delta I M P_{t-i}+\sum^{=1} \delta_{2 i} \Delta F D I_{t-i}+\sum_{=1}^{=1} \delta_{3 i} \Delta E X P_{t-i}+\delta_{4} Z_{t-1}+\varepsilon_{3 t}$

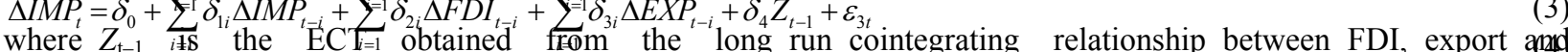
import. The above error correction model (ECM) implies that for each of the model, possible sources of causality are two: lagged dynamic regressors and lagged error correction term. If estimated coefficients of either sources of causation are found to be significant, the null of no causality is rejected. For instance, by equation (2), given volume of imports, exports Granger cause FDI, if the null of either $\sum_{i=1}^{m} \beta_{2 i}=0$ or $\beta_{4}=0$ is rejected.

\section{Results and Findings}

Applying the augmented Dickey-Fuller (ADF) tests the possible presence of unit root is checked in the paper. Table 2 reports the integration properties of the data at hand. It reveals that all three variables are nonstationary. After 1st differencing the data become stationary i.e. all three data series are difference stationary.

The variables being integrated of order 1 i.e. I (1), the series are tested for existence of any cointegrating relationship between FDI, exports and imports. The Johansen (1991) LR test of cointegration was applied and result is shown in Table 3. VAR lag is selected using Schwartz Bayesian criterion (SIC) from a maximum lag of 4, but the appropriate lag length was 2 in this case. Presence of a constant and a restricted trend is assumed in cointegrating regression. The test shows that the $\lambda$-trace statistic rejects the null of $r \leq 0$ but cannot reject $r \leq 1$ pointing to existence of cointegration.

Multivariate Granger causality test results based on equations $2-4$ (methodology section) are presented in Table 4. Here it is observed that FDI Granger causes imports and similar causality is not present between any other pair among the three variables being tested.

\section{Conclusion}

This paper aims at finding long-run relationship and causality between FDI and trade (export and import) in Bangladesh taking data between 1972 and 2007. The Johansen LR cointegration test finds cointegration between the variables. Also the multivariate Granger causality finds FDI to have caused import but causality in other directions between these and other variables is not identified. For Bangladesh foreign investment has not caused export enhancement and the necessary trade and investment policies are needed to take advantage of such foreign investment for economic growth in general and growth in trade particularly, through accumulation of positive effects of such investments. Taking more macroeconomic variables into consideration and also industry-level data and by applying more rigorous techniques, further research can be done to find the relationship between the variables to have more insights into the tested relationship between FDI and international trade.

\section{References}

Aggarwal, A. (2008). 'Regional economic integration and FDI in South Asia: prospects and problems', Indian Council for Research on International Economic Relations Working paper, no. 218

Aizenman, J. \& I. Noy ,(2005). FDI and trade- two-way linkages? National Bureau of Economic Research Working Paper Series. Cambridge, Massachusetts. No. 11403 
Bajpai, N. \& Jeffrey D. Sachs (2000). Foreign Direct Investment in India: Issues and Problems, Harvard Institute Of International Development, DDP No. 759, March.

Blomström, M., Lipsey R. E. \& K. Kulchycky (1988). US and Swedish Direct Investments and Exports in R. E. Baldwin (ed) Trade policy issues and Empirical Analysis, Chicago: University of Chicago Press.

Blonigen, Bruce A. (2001). In Search of Substitution between Foreign Production and Exports, Journal of International Economics, $\quad$ 53(1): $\quad 81-104, \quad$ doi: http://dx.doi.org/10.1016/S0022-1996(00)00066-0

Borensztein E., J. Gregrio \& J. Lee (1998). How Does Foreign Direct Investment Affect Economic Growth? Journal of International Economics 45(1), 115-135, doi:10.1016/S0022-1996(97)00033-0, http://dx.doi.org/10.1016/S0022-1996(97)00033-0

Brainard, S.L. \& D.A. Riker (1997). Are Multinationals Exporting US Jobs?, NBERWorking Paper 5958, NBER, Washington D.C.

Brainard, S.L. (1993). An Empirical Assessment of the Factor Proportions Explanation of Multinational Sales, NBER Working Paper, No. 4583, December.

Busse, M. \& Groizard, J.L. (2005). FDI, Regulations and Growth, available at: http://webs.uvigo.es/viijpe/pdf/BUSSEGRIZARD.pdf.

Chaisrisawatsuk, S. \& W. Chaisrisawatsuk, (2007). Imports, Exports and Foreign Direct Investment Interactions and Their Effects, pp.97-115, Chapter IV in ESCAP, Towards coherent policy frameworks: understanding trade and investment linkages - A study by the Asia-Pacific Research and Training Network on Trade, (United Nations, New York).

Chowdhury, A., \& Mavrotas, G., (2005). FDI and Growth: A Causal Relationship United Nations University, WIDER, Research Paper No: 2005/25.

De Mello, L.R. (1997). Foreign Direct Investment in Developing Countries and Growth: A Selective Survey, Journal of Development Studies, 34, 1-34, $\quad$ doi: $\quad 10.1080 / 00220389708422501$, http://dx.doi.org/10.1080/00220389708422501

De Mello, L.R. (1999). Foreign direct investment-led growth: Evidence from time series and panel data, Oxford Economic Papers, 51, 133-151, doi: 10.1093/oep/51.1.133, http://dx.doi.org/10.1093/oep/51.1.133

doi: 10.2307/2225181, http://dx.doi.org/10.2307/2225181

Dollar, David (1992). Outward Oriented Developing Economies Really Do Grow More Rapidly:

Domar, E.D. (1946), Capital Expansion, Rate of Growth and Employment, Econometrica, Vol. 14, pp 137-147, doi: 10.2307/1905364, http://dx.doi.org/10.2307/1905364

Ethier, Wilfred J. \& Henrik Horn, (1990). Managerial control of international fims and patterns of direct investment, Journal of international economics, 28, no.1-2, pp.25-45, doi: 10.1016/0022-1996(90)90048-Q, http://dx.doi.org/10.1016/0022-1996(90)90048-Q

Evidence from 95 LDCs, 1976-85, Economic Development and Cultural Change 523-544, doi:10.1086/451959.

Findlay, R. (1978). Relative Backwardness, Direct Foreign Investment and the Transfer of Technology: A Simple Dynamic Model, Quarterly Journal of Economics, Vol.92, No.1, pp.1-16, doi: 10.2307/1885996, http://dx.doi.org/10.2307/1885996

Geweke, J., (1982). Measurement of linear dependence and feedback between time series. Journal of the American statistical association 79, 304-324, doi: 10.2307/2287238, http://dx.doi.org/10.2307/2287238

Harrod, R F. (1939). “An Essay in Dynamic Theory,” The Economic Journal, 49, pp.14-33, ,

Helpman E., (1984). A simple theory of international trade with multinational corporations, The journal of political economy, vol.92(3),june,pp.451-471, , doi: 10.1086/261236, http://dx.doi.org/10.1086/261236

Helpman, E. \& G.M. Grossman (1991). Innovation and Growth in the Global Economy, Cambridge MA, MIT Press.

Helpman, E. \& P. Krugman, (1985). Market structure and foreign trade. Cambridge, Massachusetts, MIT Press.

Hooi Eng, Phang. (1998). Foreign Direct Investment: a study at Malaysia's balance of payments position, pelanduk publications, selangor darul ehsan, Malaysia. 
Horstmann, Ignatius J. \& J.R. Markusen (1992). Endogenous Market Structures in International Trade (Natura Facit Seltum), Journal of International Economics 32: 109-129, doi: 10.1016/0022-1996(92)90038-L, http://dx.doi.org/10.1016/0022-1996(92)90038-L

Keller, Wolfgang, (1996), Absorptive Capacity: On the Creation and Acquisition of Technology in Development, Journal of Development Economics 49: 199-227, doi: 10.1016/0304-3878(95)00060-7, http://dx.doi.org/10.1016/0304-3878(95)00060-7

Lipsey R.E. \& Weiss M. Y., (1981). Foreign production and exports in manufacturing industries, The review of Economics and Statistics, 63,pp.488-494, doi: 10.2307/1935843, http://dx.doi.org/10.2307/1935843

Liu, Xiaming, C. Wang, \& Wei, Yingqi, (2001). Causal links between foreign direct investment and trade in China. China Economic Review 12(2-3): 190-202, doi: 10.1016/S1043-951X(01)00050-5.

Lucas, R.E.J. (1988). On the Mechanics of Economic Development, Journal of Monetary Economics, 22, pp.3-42, doi: 10.1016/0304-3932(88)90168-7, http://dx.doi.org/10.1016/0304-3932(88)90168-7

Markusen J.R., (1984). Multinationals, multi-plant economics, and the gains from trade, Journal of international economics, $\quad 16, \quad$ pp.205-226, http://dx.doi.org/10.1016/S0022-1996(84)80001-X doi:10.1016/S0022-1996(84)80001-X,

Ozturk,I (2007). Foreign Direct Investment-Growth Nexus: A Review of the recent Literature, International Journal of Applied Econometrics and Quantitative Studies, vol 4, no.2, pp.79-98.

Pain, N., \& Katharine W. (1998). Export Performance and the Role of Foreign Direct Investment, The Manchester School, 66, pp. 62-88, doi: 10.1111/1467-9957.66.s.4, http://dx.doi.org/10.1111/1467-9957.66.s.4

Ramstetter, E. D. (1991). US Direct Investment in Developing Asia and Structural Adjustment in the US Manufacturing Industry in E. D. Ramstetter (ed) Direct Foreign Investment in Asia's Developing Economies and Structural Change in the Asia-Pacific Region, Boulder: Westview Press.

Rebelo, S (1991). Long-run Policy Analysis and Long-run Growth, Journal of Political Economy, 99, pp.500-521, doi: 10.1086/261764, http://dx.doi.org/10.1086/261764

Romer, P. (1986). Increasing Returns and Long-term Growth, Journal of Political Economy, Vol-94, pp 1002-1037, doi: 10.1086/261420, http://dx.doi.org/10.1086/261420

Romer, P. (1990). Endogenous Technological Change, Journal of Political Economy, Vol-98, pp. S71-S102, doi: 10.1086/261725, http://dx.doi.org/10.1086/261725

Saggi, K., (2000). Trade, Foreign Direct Investment, and International Technology Transfer: A Survey. The policy research dissemination center working paper, no. 2349, Dallas, USA.

Sahoo, P., (2006). Foreign direct investment in south asia: policy, trends, impact and determinants. ADB institute discussion paper, no. 56.

Samsu, S. H., Derus, A.M., Ooi, A. Y., \& Ghazali, M. F., (2008). Causal links between foreign direct investment and exports: evidence from Malaysia. International Journal of Business and Management, 3, pp. 177-183.

Singh, H., \& Jun, K.W. (1995). Some new evidence on determinants of foreign direct investment in developing countries. Available online at http://www.worldbank.org.

Solow, R. (1956), "A Contribution to the Theory of Economic Growth," Quarterly Journal of Economics, Vol. 70, pp. 65-94, doi: 10.2307/1884513, http://dx.doi.org/10.2307/1884513

Svensson, R. (1996), 'Effects of overseas production on home country exports: evidence based on Swedish multinationals' Weltwirtscaftliches Archiv, 132, pp.304-29, doi: 10.1007/BF02707809, http://dx.doi.org/10.1007/BF02707809

UNCTAD, Effectiveness of Foreign Direct Investment Policy Measures, Policy Note, TD/B/COM.2/EM.13/2.

Wheeler, D \& A. Mody (1992), "International Investment Location Decisions: The Case of US Firms," Journal of International Economics, Vol. 33, doi: 10.1016/0022-1996(92)90050-T, http://dx.doi.org/10.1016/0022-1996(92)90050-T

World Bank (2000). World Development Indicators, Data on CD-ROM, World Bank: Washington, DC.

World Bank (2005). World Development Indicators, Data on CD-ROM, World Bank: Washington, DC. 
Table 1. Trade Openness of different Fiscal Years

\begin{tabular}{|c|c|}
\hline Financial year & Trade openness \\
\hline $2000-01$ & 33.63 \\
\hline $2001-02$ & 30.54 \\
\hline $2002-03$ & 31.22 \\
\hline $2003-04$ & 32.76 \\
\hline $2004-05$ & 36.11 \\
\hline $2005-06$ & 38.90 \\
\hline $2006-07$ & 42.22 \\
\hline
\end{tabular}

Source: Bangladesh Bank and Ministry of Commerce

Table 2. Unit Root Test Results (ADF test)

\begin{tabular}{|l|l|l|}
\hline FDI & EXP & IMP \\
\hline-1.273 & -3.120 & -0.921 \\
\hline
\end{tabular}

Note: Optimal lag lengths for ADF and PP are selected using testing down method from a maximum lag equal to 8.

Table 3. Cointegration LR Test Results

\begin{tabular}{|c|c|c|c|}
\hline \multicolumn{3}{|c|}{$X^{\prime} \equiv[F D I, E X P, I M P] ;[$ Max VAR lag $k=4]$} \\
\hline Null & $r \leq 0$ & $r \leq 1$ & $r \leq 2$ \\
\hline$\lambda$-trace & $52.607^{*}$ & 16.419 & 2.5846 \\
{$[p$-value $]$} & {$[0.003]$} & {$[0.467]$} & {$[0.908]$} \\
\hline
\end{tabular}

Note: $r$ denotes the number of cointegrating vectors. * denotes rejection of null of no cointegration.

Table 4. Granger Causality Tests Results

\begin{tabular}{|c|c|c|c|c|}
\hline Null Hypothesis & $E X P \rightarrow F D I$ & $I M P \rightarrow F D I$ & $F D I \rightarrow E X P$ & $F D I \rightarrow I M P$ \\
\hline \multirow{2}{*}{$F$-stat } & 1.451 & 1.450 & 0.689 & 1.662 \\
& $(0.453)$ & $(0.230)$ & $(0.643)$ & $(0.240)$ \\
\hline \multirow{2}{*}{$E C T_{t-1}$} & -1.205 & -1.205 & -0.050 & $-2.830^{*}$ \\
& $(0.258)$ & $(0.258)$ & $(0.971)$ & $(0.024)$ \\
\hline
\end{tabular}

Notes: Bootstrapped p-value reported based on 1000 replications, using resampled residuals. * denotes rejection at $10 \%$ significance level. 